\title{
High Temperature Corrosion Behavior of DS GTD-111 in Oxidizing and Sulfidizing Environments
}

\author{
Matthew D. Trexler, Preet M. Singh, and Thomas H. Sanders Jr. \\ School of Materials Science and Engineering, Georgia Institute of Technology, \\ Atlanta GA 30332, United States of America
}

Keywords: nickel alloys, oxidation, sulfur environments

\begin{abstract}
Recent advances in coal combustion have made coal a cleaner, more viable source for power generation. Integrated Gasification Combined Cycle (IGCC) plants pair conventional steam turbines and coal gas turbines. The overall efficiency of each system is largely dependent on the maximum operating temperature of the system, which is limited by the available materials. Superalloys have long been used as a turbine material due to their high temperature strength and general resistance to oxidation. Superalloy GTD-111 DS is currently being used as components in steam turbine engine such as turbine blades and discs and is now being introduced to the syngas environment, which consists of $\mathrm{H}_{2}$, $\mathrm{CO}, \mathrm{CH}_{4}$, and $\mathrm{H}_{2} \mathrm{~S}$ in addition to $\mathrm{H}_{2} \mathrm{O}$. $\mathrm{H}_{2} \mathrm{~S}$ is highly corrosive and complicates the corrosion process. The high temperature corrosion behavior of a directionally solidified superalloy, GTD111 DS has been studied using thermogravimtric analysis coupled with metallographic studies. Parabolic oxidation behavior was observed for test environments including dry and wet air. Simulated syngas environments show aggressive sulfidization that leads to massive sample damage. In the case of wet syngas environments, a protective oxide layer was observed which seem to increase the samples ability to resist further corrosion.
\end{abstract}

\section{Introduction}

In IGCC systems the syngas environment is composed of mostly $\mathrm{H}_{2}, \mathrm{CO}, \mathrm{CH}_{4}, \mathrm{H}_{2} \mathrm{O}$ and $\mathrm{H}_{2} \mathrm{~S}$ in various amounts depending on the combustible material used to drive the turbine (ie. coal, black liquor etc). When considering corrosion, the key effluent gas is $\mathrm{H}_{2} \mathrm{~S}$. This is due to the fact that the other components are not largely corrosive gases and break down during combustion to form $\mathrm{CO}_{2}$ and water vapor. While these gases do not participate in the corrosion reactions, they will dictate the partial pressure of $\mathrm{H}_{2} \mathrm{~S}$ gas, which will affect the extent of corrosion. For this work a $\mathrm{H}_{2} \mathrm{~S}$ concentration of $100 \mathrm{ppm}$ was chosen. The corrosion behavior of nickel alloys in $\mathrm{H}_{2} \mathrm{~S}$ is known to be aggressive. The leading cause for this poor corrosion resistance is the formation of a low melting eutectic such as $\mathrm{Ni}_{3} \mathrm{~S}_{2}$ which melts at $745^{\circ} \mathrm{C}$, and $\mathrm{NiS}$, which melts at $975^{\circ} \mathrm{C}$ [2]. Formation of liquid films further dissolves the Ni base metal and enhances metal loss through liquid metals corrosion mechanisms [3]. The addition of water vapor to $\mathrm{H}_{2} \mathrm{~S}$ adds a competitive nature to the corrosion process. The water vapor provides ample $\mathrm{O}_{2}$ to form protective oxide films. However, in cases where molten sulfides are able to form, the oxides are destroyed and corrosion continues.

Stress free oxidation/sulfidation testing on GTD-111 was performed by Gordon et al. [1]. These tests were done in a horizontal tube furnace, here disc samples were exposed to both oxidizing and sulfur rich atmospheres for different amounts of times. The samples were sectioned and examined metallographically. Gordon's results for the oxidation tests show that GTD-111 DS is a chromia $\left(\mathrm{Cr}_{2} \mathrm{O}_{3}\right)$-forming alloy. This chromia layer serves as a protective barrier to further oxidation, which gives rise to parabolic oxidation behavior. Beneath the chromia layer is a thin compact film of rutile $\left(\mathrm{TiO}_{2}\right)$, followed by a region of internally oxidized alumina $\left(\mathrm{Al}_{2} \mathrm{O}_{3}\right)$ particles. Based on Ellingham data, alumina should be the dominant scale as it is the most stable oxide. However, most of the Al needed to form the scale is in solid solution with the $\mathrm{Ni}_{3}(\mathrm{Ti}, \mathrm{Al})\left(\gamma^{\prime}\right)$ phase. To form both $\mathrm{TiO}_{2}$ and $\mathrm{Al}_{2} \mathrm{O}_{3}$, the $\mathrm{Al}$ and Ti are stripped from the $\gamma^{\prime}$, which is a less stable phase, leaving a precipitate free zone between the scales and the base metal.

\section{Experimental Procedure}

To study high temperature corrosion of GTD-111 DS in atmospheres similar to those found in steam and IGCC turbine systems, continuous thermogravimetric analysis (TGA) studies were conducted. Rectangular samples weighing between 4 and 6 $(1.27 \times 1.27 \times 0.5 \mathrm{~cm})$ grams were cut and polished to \#600 $\mathrm{SiC}$ grit. A Cahn microbalance was used to continuously monitor the weight change as a function of time. Samples were hung inside of a vertical tube furnace using platinum wire.

Three test temperatures were selected for this work, $760^{\circ} \mathrm{C}$ $\left(1400^{\circ} \mathrm{F}\right), 871^{\circ} \mathrm{C}\left(1600^{\circ} \mathrm{F}\right)$, and $1038^{\circ} \mathrm{C}\left(1900^{\circ} \mathrm{F}\right)$. Four test atmospheres were chosen. These include both dry air and dry $\mathrm{N}_{2}$ with $100 \mathrm{ppm}_{2}$. The two remaining atmospheres included water vapor, since water is almost certainly present in any in-use system. Water was introduced in these tests by bubbling the gas through distilled water prior to being passed into the TGA. The duration of each test was 100 hours. After each TGA test the sample was removed from the furnace and placed in a Phillips $\mathrm{x}$ ray diffractometer to identify the surface scales that formed during the test. SEM imaging and EDS $x$-ray mapping were used on sectioned samples to map the outer scales and identify any subscales or internal oxidation.

\section{Results and Discussion}

Oxidation

The weight gain as a function of time for GTD-111 DS samples exposed to dry air is shown in Figure 2. For each test temperature there is a parabolic trend to the weight gain. From this data the parabolic rate constants, $\mathrm{k}_{\mathrm{p}}$, at the given test temperatures were determined. 

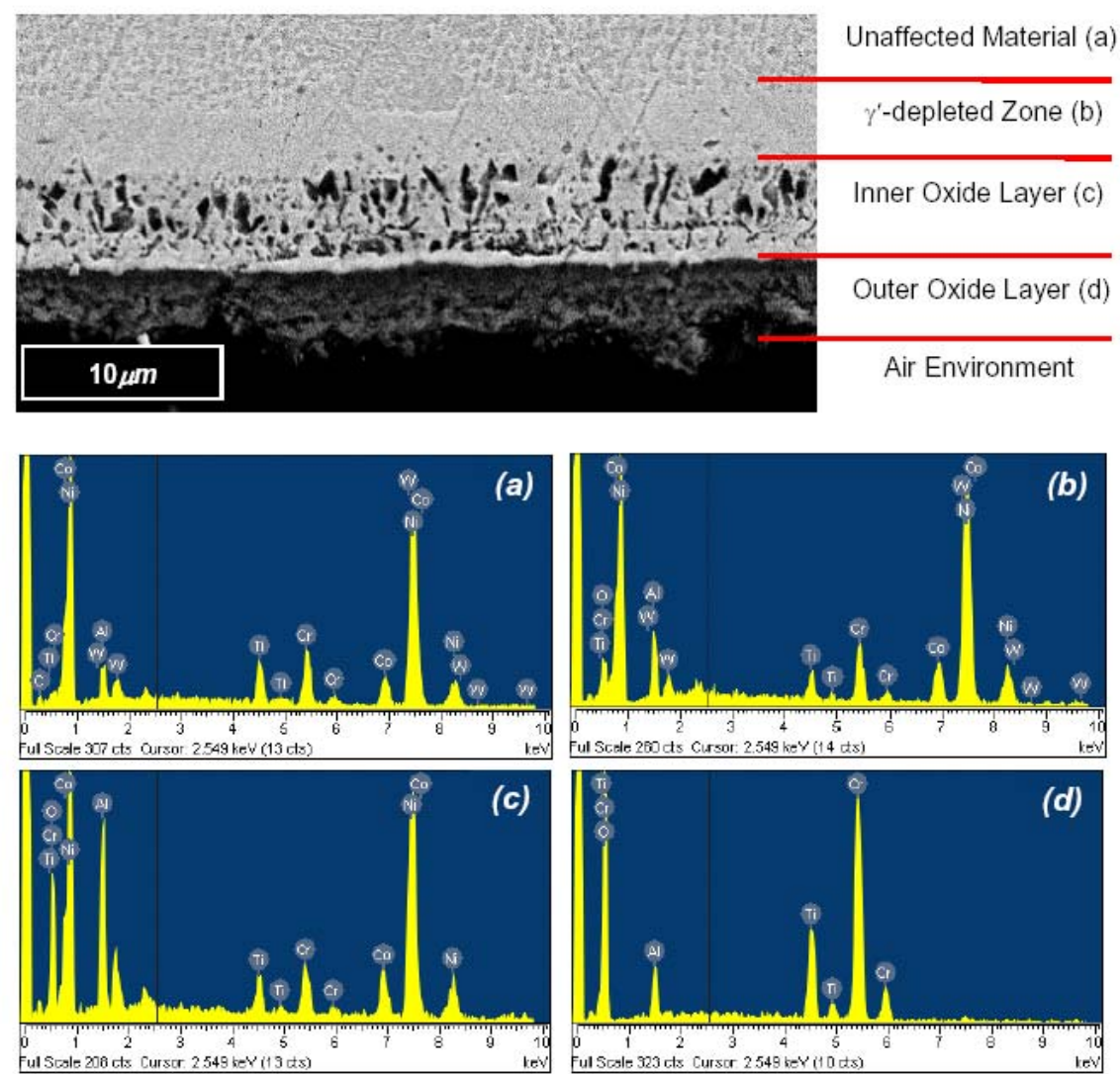

Figure 1: SEM/EDS analysis on a cross section of GTD-111 DS exposed in air at $982^{\circ} \mathrm{C}$ for 312 hours [1].

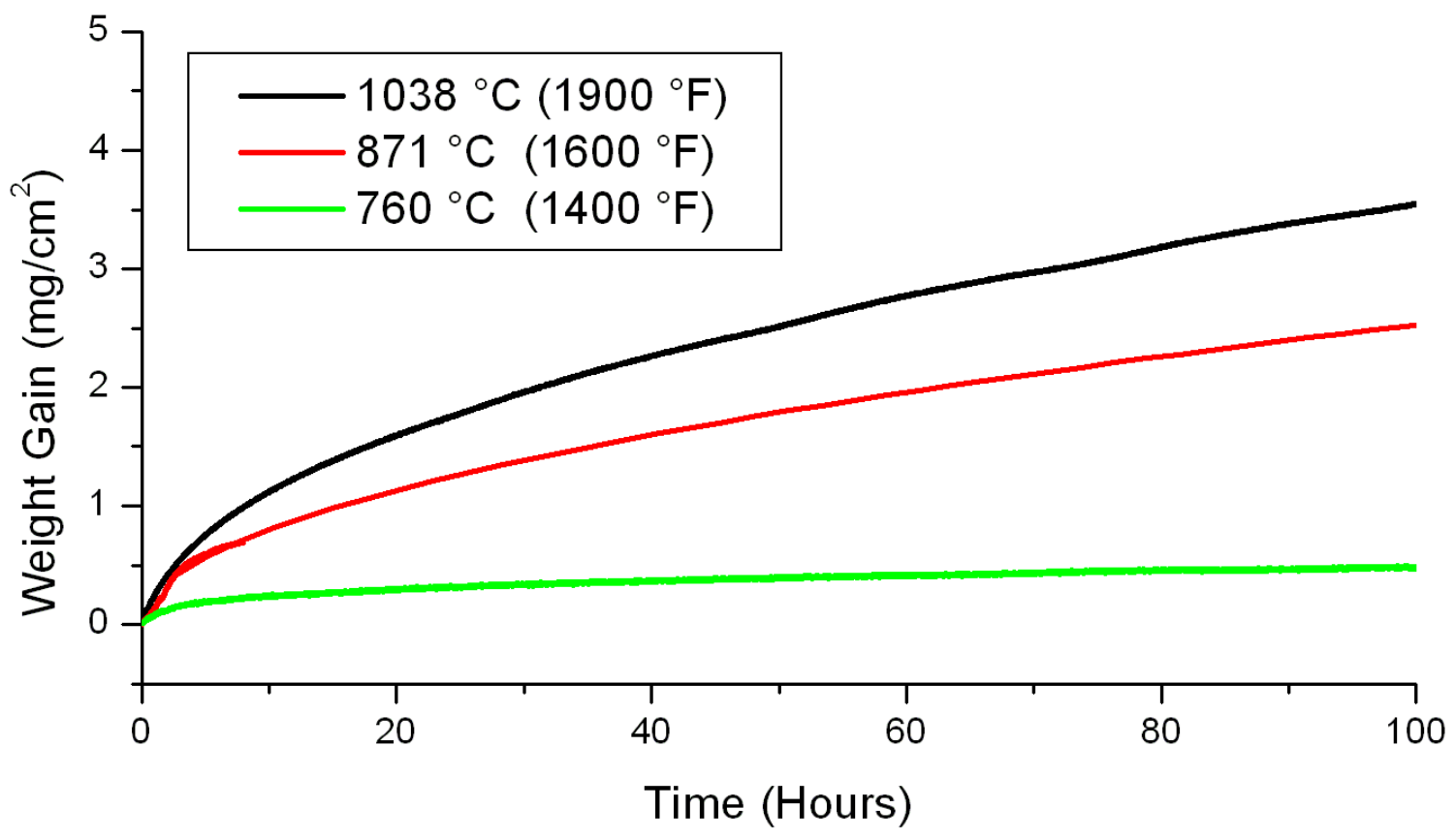

Figure 2: Weight gain versus T for GTD-111 DS at $760^{\circ} \mathrm{C}\left(1400^{\circ} \mathrm{F}\right), 871^{\circ} \mathrm{C}\left(1600 \_\mathrm{F}\right)$, and $1038^{\circ} \mathrm{C}\left(1900^{\circ} \mathrm{F}\right)$ in dry air. 
Figure 3 shows scanning electron microscope (SEM) images accompanied by EDS linescans that identify the major oxide scales formed after 100 hours in dry air. The outer most surface is a chromia $\left(\mathrm{Cr}_{2} \mathrm{O}_{3}\right)$ layer followed by a thin compact film of rutile $\left(\mathrm{TiO}_{2}\right)$. It is suggested that the rutile $\left(\mathrm{TiO}_{2}\right)$ layer plays a major role in protecting the alloy especially at higher temperatures $(>$ $1000^{\circ} \mathrm{C}$ ) where $\mathrm{Cr}_{2} \mathrm{O}_{3}$ volitizes to form $\mathrm{CrO}_{3}$ gas and can no longer protect the alloy [6]. Internally oxidized alumina $\left(\mathrm{Al}_{2} \mathrm{O}_{3}\right)$ particles are present beneath the other oxide scales. Similar micrographs were obtained for samples oxidized in wet air and show the same oxide scales.

Figure 4 is an example of an $\mathrm{x}$-ray map suggesting the presence of a thin rutile $\left(\mathrm{TiO}_{2}\right)$ layer between the outermost $\mathrm{Cr}_{2} \mathrm{O}_{3}$ layer and the internally oxidized $\mathrm{Al}_{2} \mathrm{O}_{3}$ particles. Overall, the results suggest that $\mathrm{Cr}_{2} \mathrm{O}_{3}$ is major protective scale supported by the $\left(\mathrm{TiO}_{2}\right)$ layer. At temperatures greater than $1000^{\circ} \mathrm{C}$ there is a competitive process where the growth rate of the $\mathrm{Cr}_{2} \mathrm{O}_{3}$ scale must be greater than rate of volitization. In such cases the role of $\mathrm{TiO}_{2}$ in protecting the alloy is enhanced to preserve the parabolic oxidation kinetics.

Figure 5 shows the oxidation behavior for samples tested in wet air that was obtained when dry air passed through distilled water prior to being introduced to the furnace. Figure 6 is an Arrehenius plot of the parabolic rate constants obtained for tests conducted in both dry air and air with water vapor. The increase in $\mathrm{O}_{2}$ pressure causes an increase in $\mathrm{kp}$ and only a slight change in activation energy, which is summarized in Table I. The value for Q obtained in this work is comparable to those determined by Gordon's isothermal oxidation tests. [2]

Table I: Oxidation parameters obtained for GTD-111 DS in air

\begin{tabular}{|c|c|c|l|}
\hline \multicolumn{2}{|c|}{ Temperature } & Dry Air & Wet Air \\
\hline${ }^{\circ} \mathrm{C}$ & ${ }^{\circ} \mathrm{F}$ & $\mathrm{k}_{\mathrm{p}}\left(\mathrm{mg}^{2} / \mathrm{cm}^{4} \mathrm{~h}\right.$ & $\mathrm{k}_{\mathrm{p}} \mathrm{mg}^{2} / \mathrm{cm}^{4} \mathrm{~h}$ \\
\hline 760 & 1200 & 0.002 & 0.004 \\
\hline 871 & 1400 & 0.0697 & 0.01098 \\
\hline 1038 & 1900 & 0.1248 & 0.12386 \\
\hline Q (kjoules/mole) & 71.1 & 63.8 \\
\hline
\end{tabular}

\section{$\underline{\text { Sulfidation }}$}

The TGA results for GTD-111 DS tested in dry $\mathrm{N}_{2} 100$ ppm $\mathrm{H}_{2} \mathrm{~S}$ are shown in Figure7. The weight gain at $760^{\circ} \mathrm{C}$ proceeds linearly until the weight nearly doubles ( $45 \%$ gain). Massive damage was experienced by the sample, resulting in the sample splitting in half as can be seen in Figure 8. This was attributed to the formation of liquid sulfides in a grain boundary. In the cases of samples tested wet $\mathrm{H}_{2} \mathrm{~S}$ at $871^{\circ} \mathrm{C}$, para-linear oxidation was observed. A protective barrier is initially formed and remains intact for approximately 50 hours, at which point breakdown of the film occurs and the weight gain continues in a linear fashion. It is the activation energy from $50.3 \mathrm{kjoules} / \mathrm{mole}$, for the dry case to $69.2 \mathrm{kjoules} / \mathrm{mole}$ for the case conducted with water. It is suggested that the breakdown of the film is due to "slagging" mechanism in which molten NiS destroys the barrier and weight gain continues. Two reactions take place during the process. The first reaction is the formation of sulfide scales that account for the weight gain. The second reaction is the volatization of this scale as the molten sulfide layer boils off of the surface. This is supported by small NiS spheres and a relatively clean surface on the $1038^{\circ} \mathrm{C}$ sample (Figure 9). The experimental configuration used in this work was unable to monitor the volume of material that may boil off the sample. Hence, weight gain alone cannot represent the degradation of the material since weight is being simultaneously gained and lost.

To account for the damage to samples tested at $1038^{\circ} \mathrm{C}$, samples were exposed at $1038^{\circ} \mathrm{C}$ in $\mathrm{N}_{2}$ for varying amounts of time. After testing, the weight of these samples was measured, and then the outer scale was removed by sand blasting. This allowed the amount of metal that was lost in the corrosion process, as a function of time, to be determined, which is shown in Figure 10.

As the exposure time increases, metal is being consumed, either forming a sulfide scale that remains on the sample, which accounts for the weight gain measured by the TGA, or forming a molten sulfide that volatizes, leaves the sample and is lost in the exhaust of the experiment. At this time it is important to also state that the differences between these three curves may also be largely dependent on the number of grain boundaries that are present in each sample as it was noticed that grain boundaries are preferentially attacked due to enhance diffusion.

The addition of water vapor to the $\mathrm{N}_{2}$ with $100 \mathrm{ppm} \mathrm{H}_{2} \mathrm{~S}$ gas mixture introduced an $\mathrm{O}_{2}$ source, allowing the formation of protective oxides that further hinder attack by $\mathrm{H}_{2} \mathrm{~S}$. In fact, preoxidized nickel based superalloys have been shown to be more resistant to $\mathrm{H}_{2} \mathrm{~S}$ due to compact oxide films [4-6]. Figure 12 is a plot of the weight gain as a function of time for GTD-111 DS in $\mathrm{N}_{2}$ with $100 \mathrm{ppm} \mathrm{H}_{2} \mathrm{~S}$ bubbled through distilled water. At room temperature, the solubility of $\mathrm{H}_{2} \mathrm{~S}$ in water is minimal [6], which ensures that only water vapor was introduced to the gas stream and that sulfur was not being trapped in the water. Parabolic kinetics was observed for the $760^{\circ} \mathrm{C}$. The total weight gain in the atmosphere consisting of wet $\mathrm{N}_{2}$ with $100 \mathrm{ppm}_{2} \mathrm{~S}$ was 0.828 $\mathrm{mg} / \mathrm{cm}^{2}$. This was an order of magnitude higher than the weight gain seen $\left(0.087 \mathrm{mg} / \mathrm{cm}^{2}\right)$ in the wet air test. This suggests that while formation of a protective oxide layer is possible in both cases, the sulfur is also attacking the base metal, possibly because the oxide is porous or locally absent, which allows sulfur access to the surface. The results indicate that the effect of $\mathrm{H}_{2} \mathrm{~S}$ is diminished in oxygen containing environments such as dry and wet air.

The addition of water to $\mathrm{H}_{2} \mathrm{~S}$ gas yielded similar mass gains to the results from the air tests. At $871^{\circ} \mathrm{C}$ para-linear oxidation is observed, which was not observed in the wet air test. A thick oxide can be seen on the surface. At $1038^{\circ} \mathrm{C}$, there is an initial linear increase in weight, which transitions to parabolic behavior as a compact oxide scale is formed. An Arrhenius plot was used to determine the activation energies for corrosion in both dry and wet $\mathrm{N}_{2}$ with $100 \mathrm{ppm} \mathrm{H}_{2} \mathrm{~S}$ for samples that showed parabolic behavior. Figure 14 shows that the activation energy from 50.3 kjoules/mole, for the dry case to 69.2 kjoules/mole for the case conducted with water. 

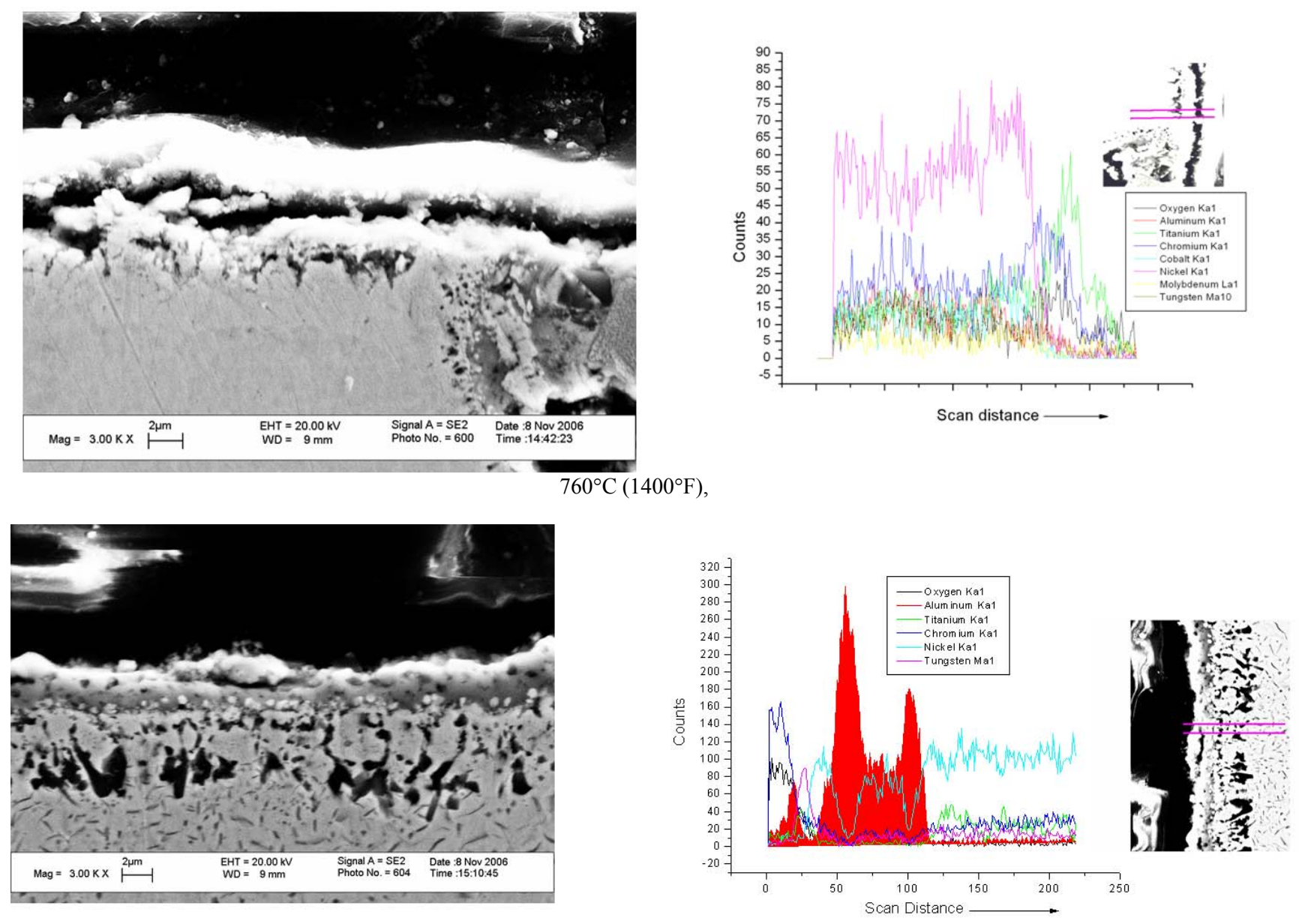

$871^{\circ} \mathrm{C}\left(1600^{\circ} \mathrm{F}\right)$
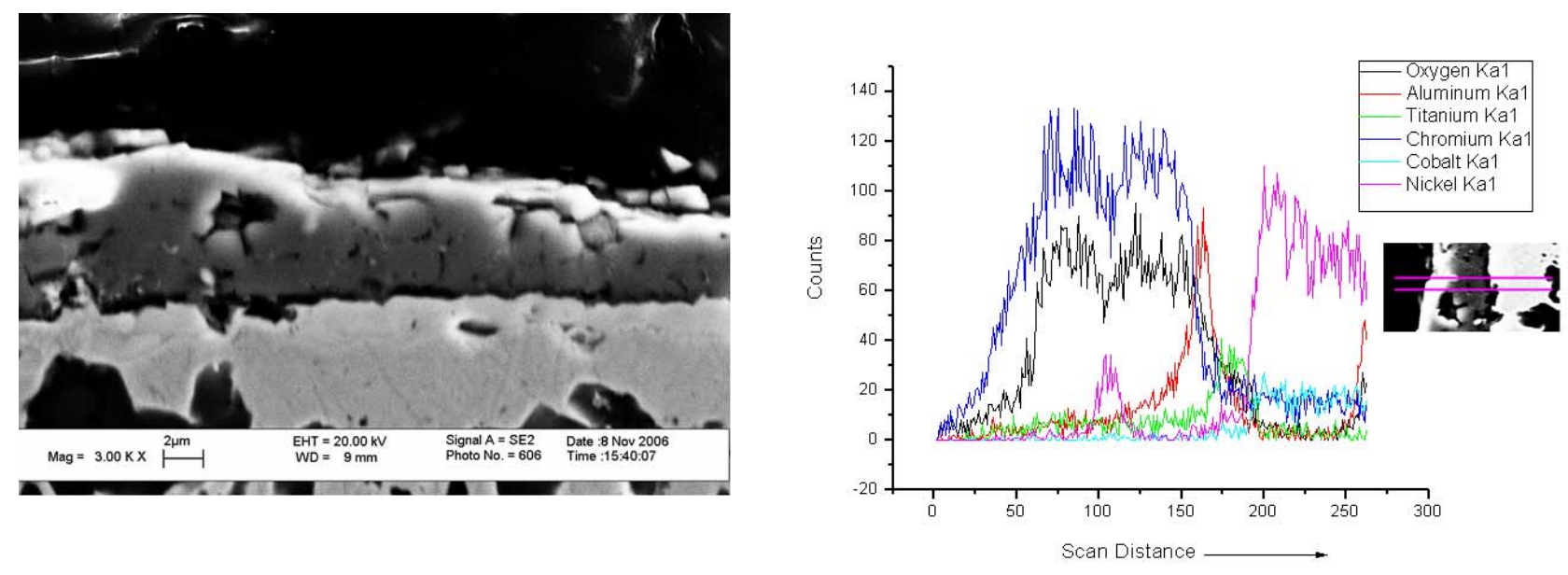

$1038^{\circ} \mathrm{C}\left(1900^{\circ} \mathrm{F}\right)$

Figure 3: Scanning electron microscope (SEM) GTD-111 DS tested at $760^{\circ} \mathrm{C}\left(1400^{\circ} \mathrm{F}\right), 871^{\circ} \mathrm{C}\left(1600^{\circ} \mathrm{F}\right)$, and $1038^{\circ} \mathrm{C}\left(1900^{\circ} \mathrm{F}\right)$ in dry air. 

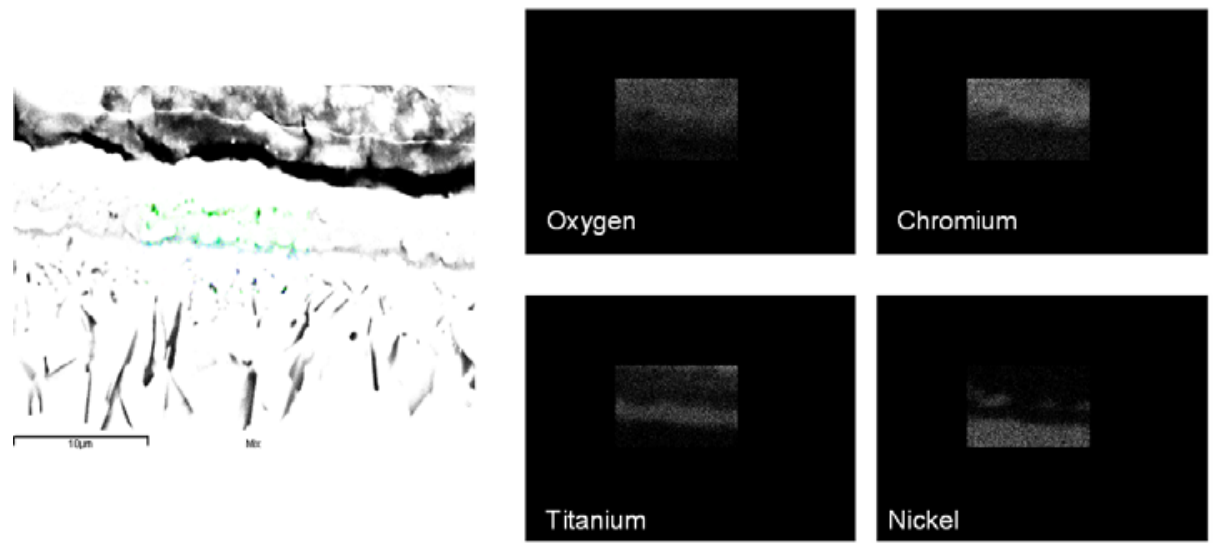

Figure 4: $\mathrm{X}$-ray map of oxide layer form after $100 \mathrm{hr}$ at $871^{\circ} \mathrm{C} 1400^{\circ} \mathrm{F}$ in wet air.

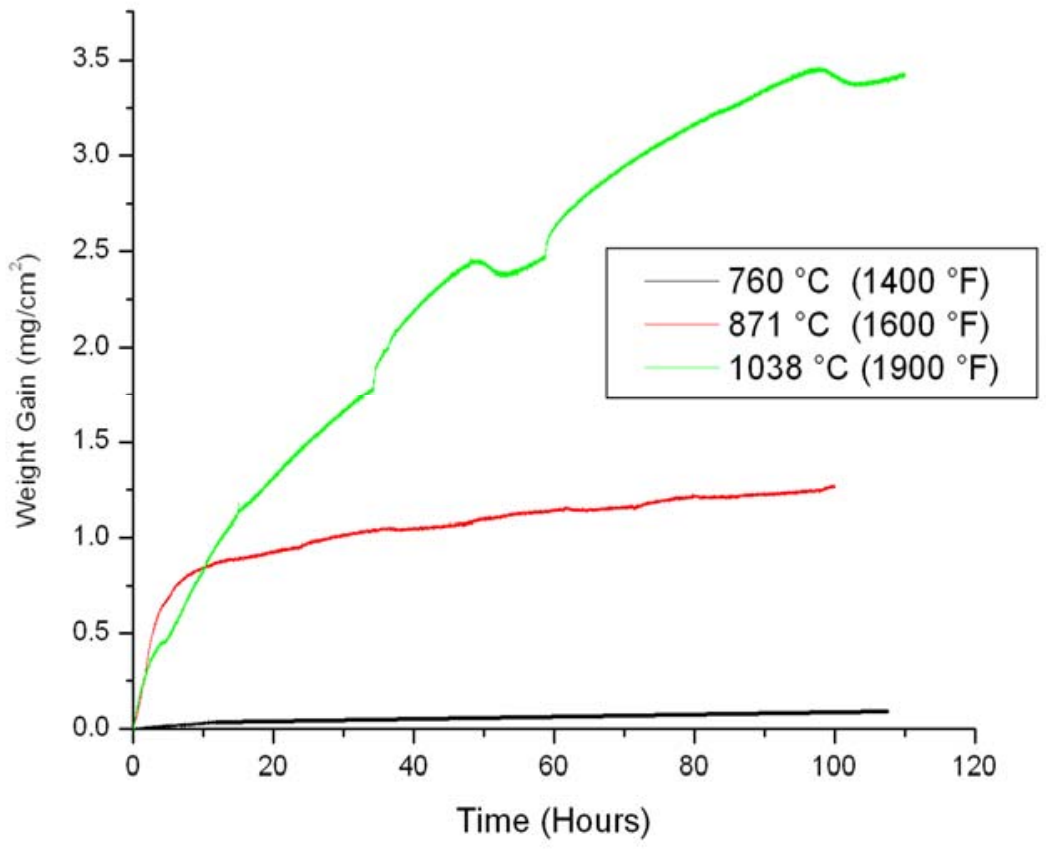

Figure 5: Weight gain versus $\mathrm{T}$ for GTD-111 DS at $760^{\circ} \mathrm{C}\left(1400^{\circ} \mathrm{F}\right), 871^{\circ} \mathrm{C}\left(1600^{\circ} \mathrm{F}\right)$, and $1038^{\circ} \mathrm{C}\left(1900^{\circ} \mathrm{F}\right)$ in wet air. 


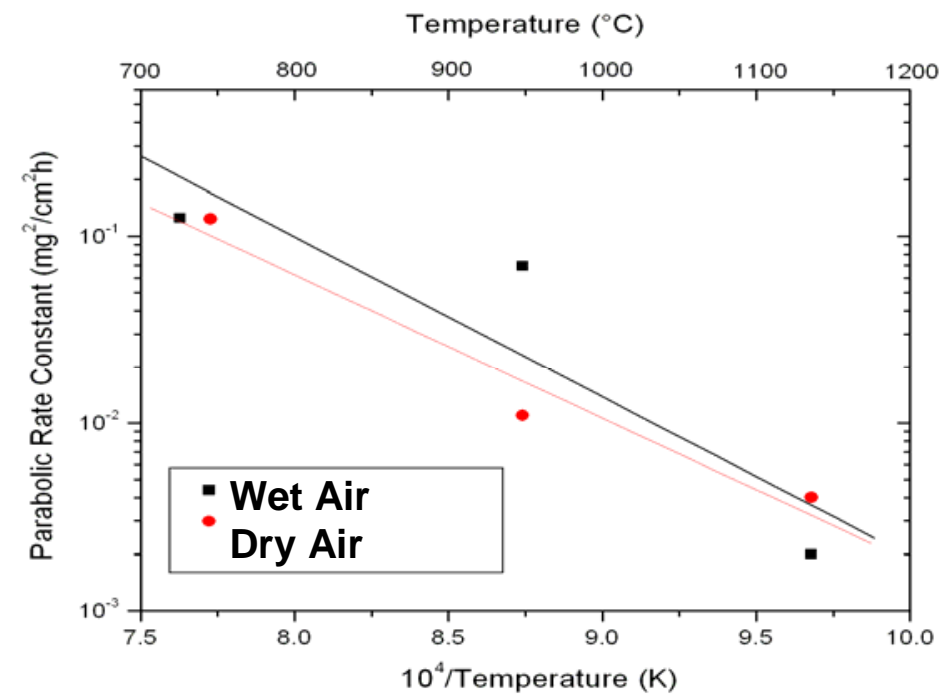

Figure 6: Arrhenius plot of parabolic rate constants versus $10^{4} / \mathrm{T}$ for GTD-111 DS in dry air and wet air cases.

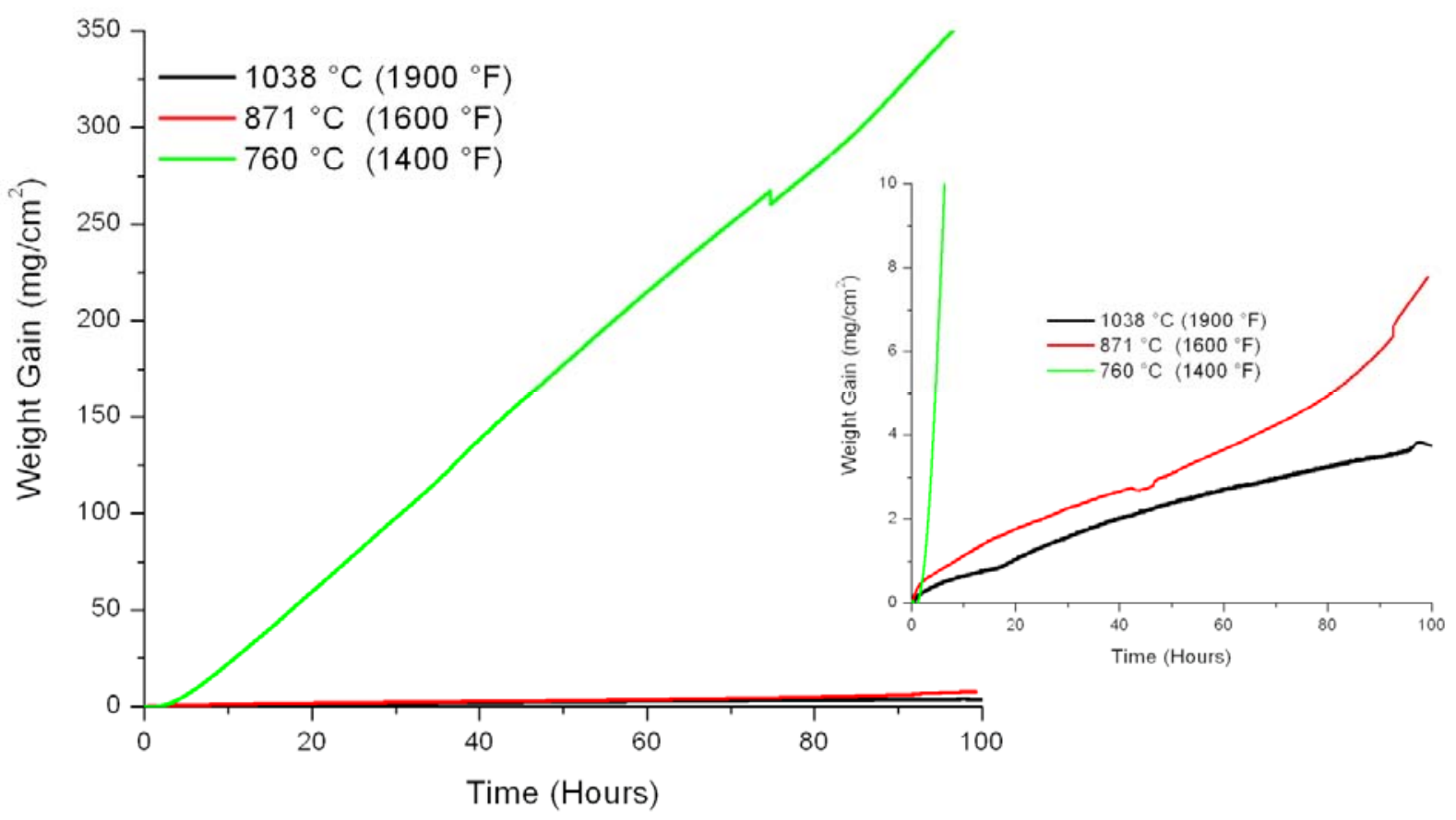

Figure 7: Weight gain versus $\mathrm{T}$ for GTD-111 DS at $760^{\circ} \mathrm{C}\left(1400^{\circ} \mathrm{F}\right), 8^{\circ} \mathrm{C}\left(1600^{\circ} \mathrm{F}\right)$, and $1038^{\circ} \mathrm{C}\left(1900^{\circ} \mathrm{F}\right)$ in $\mathrm{N}_{2}$ with 100 ppm $\mathrm{H}_{2} \mathrm{~S}$. 


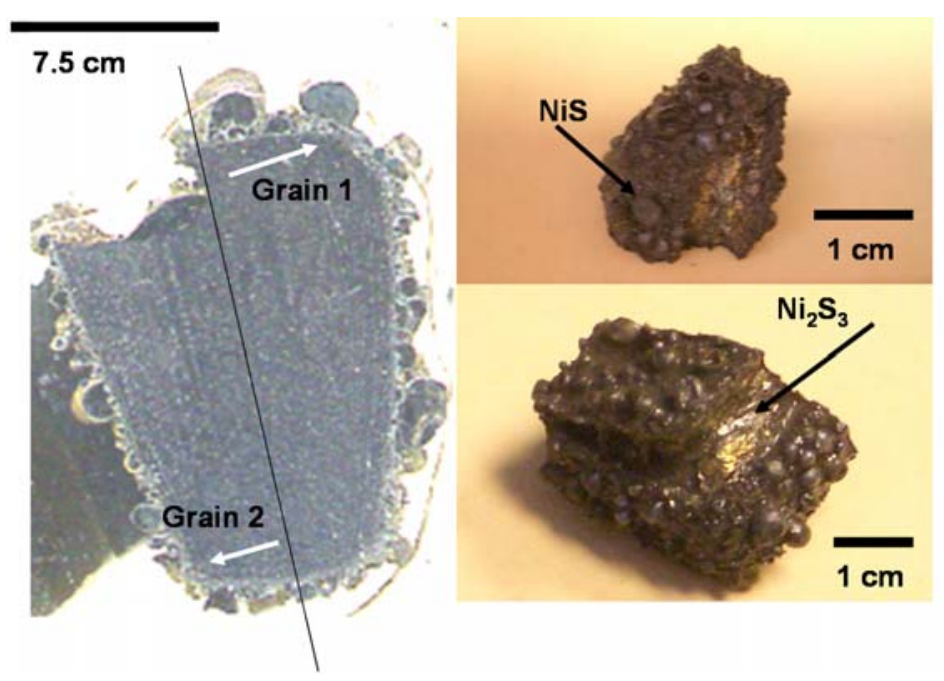

Figure 8: Images of a sample tested at $760^{\circ} \mathrm{C}$ that shows massive grain boundary corrosion that "splits" the sample along a grain boundary. The corrosion product on the outer edge of the sample is NiS. As S diffuses further into the sample, the "splitting" agent at the grain boundary, $\mathrm{Ni}_{2} \mathrm{~S}_{3}$, is formed as denoted by the arrow (lower right).
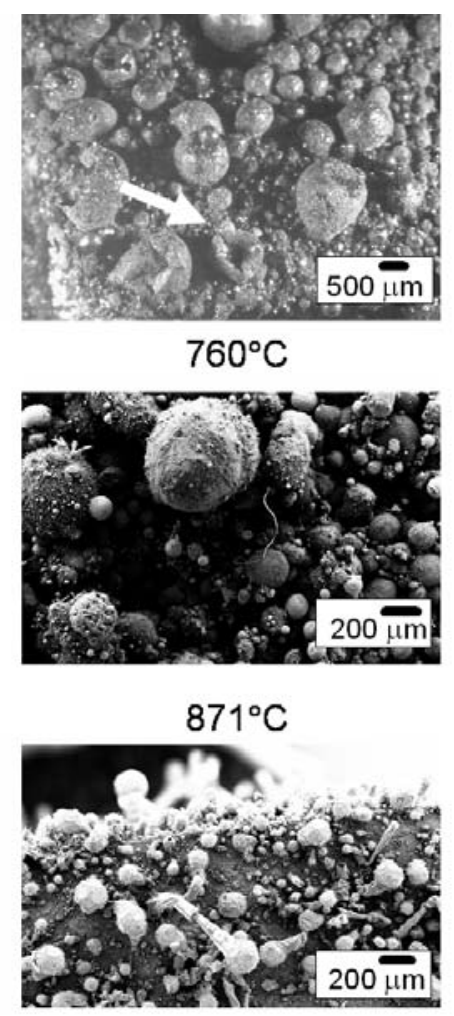

$1038^{\circ} \mathrm{C}$

Figure 9: Micrographs of samples tested at $760^{\circ} \mathrm{C}\left(1400^{\circ} \mathrm{F}\right), 871^{\circ} \mathrm{C}\left(1600^{\circ} \mathrm{F}\right)$, and $1038^{\circ} \mathrm{C}\left(1900^{\circ} \mathrm{F}\right)$ in $\mathrm{N}_{2}$ with $100 \mathrm{ppm} \mathrm{H}_{2} \mathrm{~S}$, which show NiS spheroids. These spheroids were formed as the molten sulfide cooled after the test. The relative size of the spheres decreased as temperature increased, which is attributed to increased boiling kinetics. The arrows points to bubbles that have burst and frozen on the surface of the samples. 


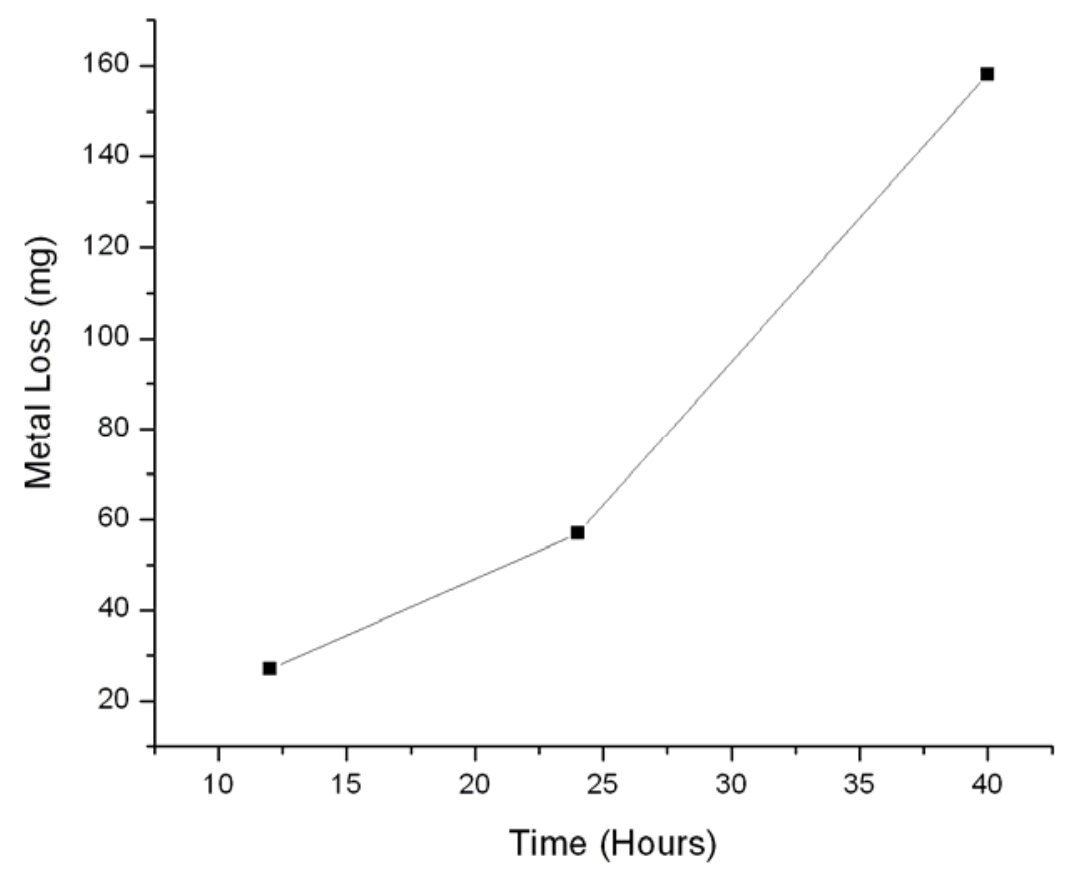

Figure 10: Metal loss versus T for GTD-111 DS at $1038^{\circ} \mathrm{C}\left(1900^{\circ} \mathrm{F}\right)$ in $\mathrm{N}_{2}$ with $100 \mathrm{ppm} \mathrm{H}_{2} \mathrm{~S}$.

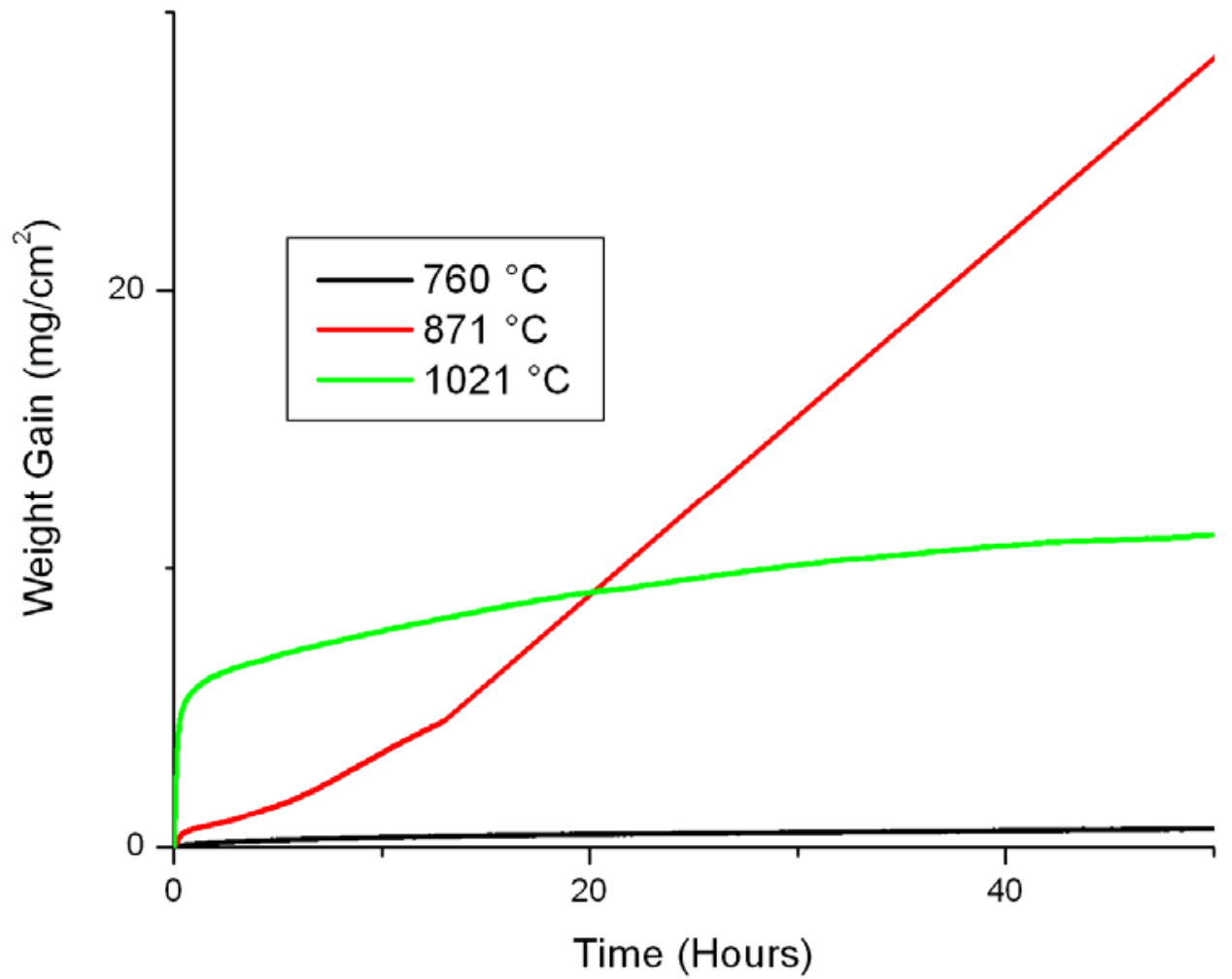

Figure 11: Weight gain versus $\mathrm{T}$ for GTD-111 DS at $760^{\circ} \mathrm{C}\left(1400^{\circ} \mathrm{F}\right), 871^{\circ} \mathrm{C}\left(1600^{\circ} \mathrm{F}\right)$, and $1038^{\circ} \mathrm{C}\left(1900^{\circ} \mathrm{F}\right)$ in wet $\mathrm{N}_{2}$ with $100 \mathrm{ppm}$. 

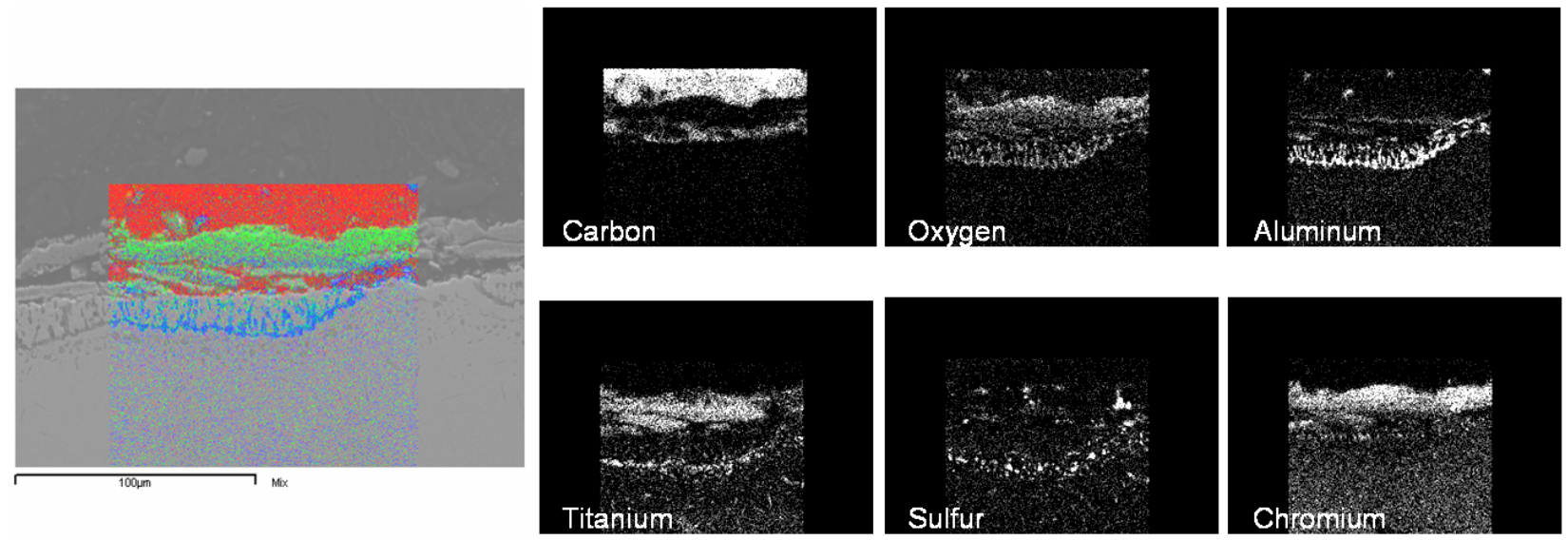

Figure 13: EDS x-ray map of a GTD-111 DS sample tested at $1038^{\circ} \mathrm{C}\left(1900^{\circ} \mathrm{F}\right)$ in wet $\mathrm{N}_{2}$ with $100 \mathrm{ppm}$.

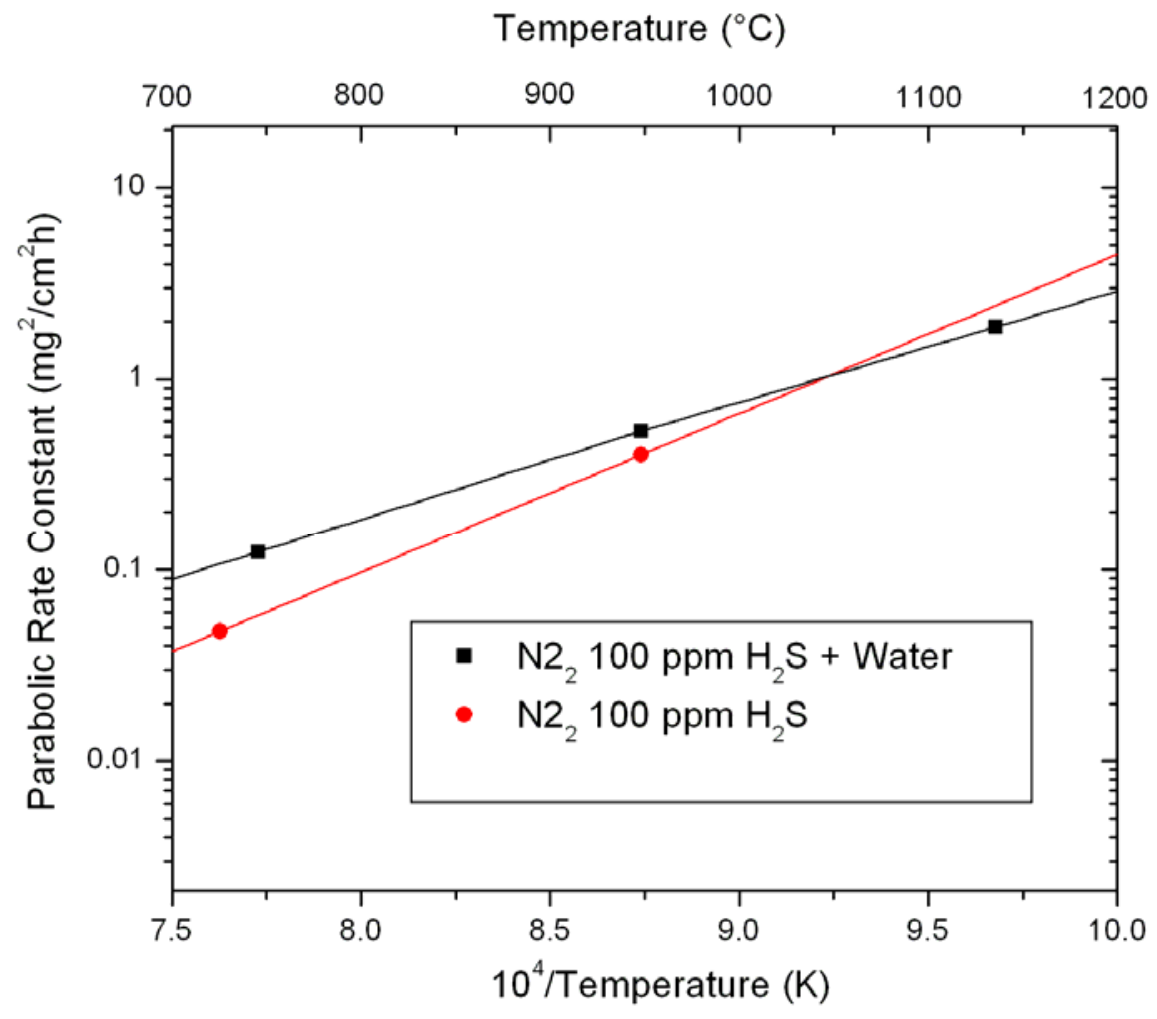

Figure 14: Arrhenius plot of parabolic rate constants versus $10^{4} / \mathrm{T}$ for GTD-111 DS in dry $\mathrm{N}_{2} 100 \mathrm{ppm} \mathrm{H}_{2} \mathrm{~S}$ and wet $\mathrm{N}_{2}$ with 100 ppm. 


\section{Conclusions}

High temperature oxidation/sulfidation test were conducted in both dry and wet conditions. Parabolic oxidation kinetics was observed in most samples and a direct link between grain boundaries corrosion was observed. The significance of the work presented in this chapter towards steam and IGCC turbines can be summarized by:

1. TGA testing at $760^{\circ} \mathrm{C}, 871^{\circ} \mathrm{C}$, and $1038^{\circ} \mathrm{C}$ in dry air confirmed parabolic oxidation behavior.

2. The addition of water vapor to the air increases the parabolic rate constant, $\mathrm{k}_{\mathrm{p}}$, but has a minimal effect on the activation energy, $\mathrm{Q}\left(\mathrm{Q}_{\mathrm{Dry}}=71.1 \mathrm{kjoule} / \mathrm{mole}, \mathrm{Q}_{\mathrm{Wet}}\right.$ $=63.8 \mathrm{kjoule} / \mathrm{mole}$ ) of approximately $10 \%$.

3. The activation energies of samples tested in $\mathrm{N}_{2}$ with 100 ppm $\mathrm{H}_{2} \mathrm{~S}$ are lower than those of samples tested in dry air $\left(\mathrm{Q}_{\text {Dry }}=-50.3 \mathrm{kjoule} / \mathrm{mole}, \mathrm{Q}_{\mathrm{Wet}}=-69.2\right.$

kjoule/mole). The increase in activation energies with $\mathrm{O}_{2}$ was attributed to the formation of oxide scales, which hinder corrosion.

4. Grain boundary "splitting" was observed at $760^{\circ} \mathrm{C}$ and $871^{\circ} \mathrm{C}$ in $\mathrm{N}_{2}$ with 100 ppm $\mathrm{H}_{2} \mathrm{~S}$ due to enhanced diffusion.

\section{References}

1. Ali Gordon. $\mathrm{PhD}$ thesis, Georgia Institute of Technology, 2005.

2. Mineral of the Month Club. http://webmineral.com/data/Heazlewoodite.shtml, 10/30/2006.

3. Denny A. Jones. Principle and Prevention of Corrosion. Macmillan Publishing Co., 1992.

4. A.S. Khanna. Introduction to High Temperature Oxidation and Corrosion. ASM Internation, 2002.

5. ASM. ASM HANDBOOK VOLUME 13: Corrosion, volume 13. 1987.

6. Apache Corp. Msds hydrogen sulfide. http://www.apachecorp.com/, 11/05/2006.

\section{Acknowledgments}

The work discussed in this paper is the result of partial support from General Electric Energy, the Department of Energy, and Institute of Paper Science and Technology. 